\title{
Chondrichthyan Diversity, Conservation Status, and Management Challenges in Costa Rica
}

\author{
Mario Espinoza ${ }^{1,2 *}$, Eric Díaz ${ }^{3}$, Arturo Angulo ${ }^{1,4,5}$, Sebastián Hernández ${ }^{6,7}$ and \\ Tayler M. Clarke ${ }^{1,8}$
}

${ }^{1}$ Centro de Investigación en Ciencias del Mar y Limnología, Universidad de Costa Rica, San José, Costa Rica, ${ }^{2}$ Escuela de Biología, Universidad de Costa Rica, San José, Costa Rica, ${ }^{3}$ Escuela de Ciencias Exactas y Naturales, Universidad Estatal a Distancia, San José, Costa Rica, ${ }^{4}$ Museo de Zoología, Universidad de Costa Rica, San José, Costa Rica, ${ }^{5}$ Laboratório de Ictiologia, Departamento de Zoologia e Botânica, UNESP, Universidade Estadual Paulista "Júlio de Mesquita Filho", São José do Rio Preto, Brazil, ${ }^{6}$ Biomolecular Laboratory, Center for International Programs, Universidad VERITAS, San José, Costa Rica, ${ }^{7}$ Sala de Colecciones Biologicas, Facultad de Ciencias del Mar, Universidad Catolica del Norte, Antofagasta, Chile, ${ }^{8}$ Changing Ocean Research Unit, Institute for the Oceans and Fisheries, The University of British Columbia, Vancouver, BC, Canada

\section{OPEN ACCESS}

Edited by:

Steven W. Purcell,

Southern Cross University, Australia

Reviewed by:

Mourier Johann,

USR3278 Centre de Recherche Insulaire et Observatoire de L'environnement (CRIOBE), France

Alexander Tilley,

WorldFish, Malaysia

*Correspondence:

Mario Espinoza

marioespinozamen@gmail.com

Specialty section:

This article was submitted to Marine Fisheries, Aquaculture and

Living Resources,

a section of the journal

Frontiers in Marine Science

Received: 04 December 2017

Accepted: 27 February 2018

Published: 13 March 2018

Citation:

Espinoza M, Díaz E, Angulo A, Hernández S and Clarke TM (2018)

Chondrichthyan Diversity,

Conservation Status, and Management Challenges in Costa

Rica. Front. Mar. Sci. 5:85.

doi: 10.3389/fmars.2018.00085
Understanding key aspects of the biology and ecology of chondrichthyan fishes (sharks, rays, and chimeras), as well as the range of threats affecting their populations is crucial given the rapid rate at which some species are declining. In the Eastern Tropical Pacific (ETP), the lack of knowledge, unreliable (or non-existent) landing statistics, and limited enforcement of existing fisheries regulations has hindered management and conservation efforts for chondrichthyan species. This review evaluated our current understanding of Costa Rican chondrichthyans and their conservation status. Specifically, we (1) provide an updated checklist on the species richness, habitat use, and distribution patterns, (2) summarize the most relevant chondrichthyan studies (scientific publications, theses, and official technical reports), (3) identify knowledge gaps, (4) discuss fisheries-related threats, and (5) highlight the management challenges and research needs to effectively protect their populations. A total of 99 chondrichthyan species are formally recorded in Costa Rican waters, from which $15 \%$ are threatened with extinction and $41 \%$ are "Data Deficient" based on the IUCN (International Union for Conservation of Nature) Red List. A total of 121 studies were published between 1891 and 2017; 82\% in the Pacific (24\% from Isla del Coco) and only 18\% from the Caribbean Sea. These results highlight the need to redirect research efforts on specific taxonomic groups and geographic regions (i.e., Caribbean). Based on our review, improving the quality and quantity of fisheries landing statistics, as well as determining the degree of overlap between chondrichthyans and Costa Rican fisheries remains a priority. We proposed an adaptive management framework for chondrichthyan fisheries in data-poor countries where management goals/targets are clearly defined. This framework could strengthen the conservation of chondrichthyan populations in Costa Rica and the region.

Keywords: sharks, rays, chimeras, population declines, management, conservation approaches, data-poor countries, Eastern Tropical Pacific 


\section{INTRODUCTION}

In many regions, chondrichthyan populations (sharks, rays, and chimeras) have been reduced to unsustainable levels (WardPaige et al., 2010; Davidson et al., 2016; Spaet et al., 2016), raising global concern over their conservation status (Dulvy et al., 2014, 2017). Some chondrichthyans have life-history traits (slow growth rates, late maturities, low fecundities, and long gestation periods) which make them less resilient to fishing, even at low levels of exploitation (Frisk et al., 2001). Recent assessments, for example, estimated that one-quarter of the world's chondrichthyans were threatened with extinction as a result of overfishing (Dulvy et al., 2014; Davidson et al., 2016). Moreover, Dulvy et al. (2014) highlighted the current lack of information on many chondrichthyans, particularly batoids (rays and skates), as almost half of the species assessed were listed as "Data Deficient."

While overfishing has been identified as the main driver of chondrichthyan population declines, habitat loss/degradation, and climate change can also play significant roles (García et al., 2008; Chin et al., 2010; Dulvy et al., 2014). Sawfishes (Pristidae) and freshwater stingrays (Potamotrygonidae), for instance, have a greater affinity for freshwater and estuarine habitats (Carrier et al., 2010; Norton et al., 2012), all of which are largely affected by human practices (e.g., agriculture, aquaculture, hydroelectric power stations), and/or rapid and unplanned coastal/riverine development (Peverell, 2009; Hossain et al., 2015). Moreover, many coastal elasmobranchs (sharks and rays) utilize a wide range of inshore habitats during their early stages as feeding, reproduction, and/or nursery grounds (Heupel et al., 2007; Jirik and Lowe, 2012; Tobin et al., 2014; Chapman et al., 2015). In addition, climatedriven changes in the physical, chemical, and biological conditions of chondrichthyan habitats have the potential to affect their distribution, movement, feeding ecology, reproduction, and growth (Chin et al., 2010; Dulvy et al., 2014; Pistevos et al., 2015). Therefore, understanding the range of anthropogenic and environmental drivers that influence (directly or indirectly) chondrichthyan populations is crucial to designing more effective management approaches to improve their conservation.

In many countries from the Eastern Tropical Pacific (ETP), the current status of chondrichthyans is unclear (Rojas et al., 2000; Dapp et al., 2013; Clarke et al., 2017). Moreover, the lack of biological and ecological data, unreliable (or nonexistent) landing statistics, and limited enforcement of existing management regulations has hindered conservation efforts for sharks, rays, and chimeras that are currently threatened in this region. In Costa Rica, for example, reconstructed shark catches were estimated to be $83 \%$ higher than FAO statistics, while national landing statistics were $60 \%$ lower than FAO landing statistics (Trujillo et al., 2015). Moreover, illegal fishing activities, even in remote Marine Protected Areas (MPAs) and UNESCO World Heritage Sites such as Cocos (Arias et al., 2014; White et al., 2015; López-Garro et al., 2016) and Galapagos Islands (Sills, 2017) are threatening the future of migratory shark stocks within the ETP.
Over the past decades, marine research in Costa Rica has grown considerably (Wehrtmann and Cortés, 2009), yet chondrichthyan science continues to be overlooked. Given the rapid rate at which some species are declining, their vulnerability to increasing market demands (especially for their fins) and the uncertainty about the distribution and status of the ETP chondrichthyan stocks (Dent and Clarke, 2015; Davidson et al., 2016), it is essential to (i) identify knowledge gaps and establish research priorities at a regional scale, (ii) assess non-listed and data-deficient species, and (iii) bridge the gap between science and policy. This review evaluated the current knowledge and conservation status of Costa Rican chondrichthyans. Specifically, we (1) provide an updated checklist on the species richness, habitat use and distribution patterns, (2) summarize the most relevant chondrichthyan studies (scientific publications, theses, and official technical reports), (3) identify knowledge gaps, (4) discuss fisheries-related threats, and (5) highlight the management challenges and research needs to effectively protect their populations. Moreover, we proposed an adaptive management framework for chondrichthyan fisheries in Costa Rica, which may be applicable to other data-poor countries from the ETP.

\section{METHODS}

\section{Updated Checklist: Species Richness and Distribution Patterns}

Diversity and distribution data for chondrichthyans in Costa Rican waters were obtained from a detailed review of available scientific data, species occurrence records, and fish collections (e.g., Bussing and López, 2009; Robertson and Allen, 2015; Robertson and Van Tassell, 2015). Species occurrence records were obtained by querying the database FishNet2 (http://www. fishnet2.net/aboutFishNet.html) and the digital catalog of the fish collection of the Museo de Zoología of the Universidad de Costa Rica (UCR). Specimens from UCR were revised and re-identified. Our search resulted in a checklist of chondrichthyan species with confirmed occurrence records (i.e., species formally recorded in the literature and/or with voucher specimens collected in Costa Rica) as well as those expected to occur in Costa Rica (based on known or postulated distributions; i.e., species with wide distribution ranges that may include Costa Rican waters, but for which there are still no formal records). This checklist was arranged by order and family following Eschmeyer and Fong (2017), and is provided in Appendix I in Supplementary Material. The following information for each species is provided: valid scientific name with author(s) and year of description, following Eschmeyer et al. (2017); popular, technical, and/or vernacular names in English (En) and Spanish (Sp), following Robertson and Allen (2015), Robertson and Van Tassell (2015), and Froese and Pauly (2017); current known geographical distribution, depth range and habitat use following Robertson and Allen (2015), Robertson and Van Tassell (2015), Weigmann (2016), and Froese and Pauly (2017); conservation status, according to the International Union for Conservation of Nature (IUCN) Red List criteria (IUCN, 2017); and relevant literature [relatively recent 
references arbitrarily considered by us to have taxonomic and/or distributional value by providing short diagnosis, identification keys, illustrations, and/or distribution (geographical and depth) information, not mere usage of the specific names].

\section{Literature Search of Chondrichthyan Studies in Costa Rica}

Detailed searches for scientific publications, theses, technical reports, and books related to chondrichthyans in Costa Rican waters were conducted until November 2017, using Google Scholar, SIDUNA (Documentary Information System of the National University), Shark-References (http://shark-references. $\operatorname{com} /$ ), and SIBDI (System of Libraries, Documentation, and Information from Universidad de Costa Rica). The online search was based on the following keyword combinations: "[(sharks or shark) AND (rays or ray) AND (chimera or chimeras) AND (elasmobranch or elasmobranchs) AND (chondrichthyans or chondrichthyes) AND Costa Rica]." This search identified 526 studies that contained any of the keyword combinations. We filtered the resulting publication list to exclude studies that were not conducted in Costa Rica and did not include at least one chondrichthyan species, for a final publication list of 121 studies. To determine the current state of knowledge and general information gaps, chondrichthyan studies were classified in one of the following topics: (i) fisheries and management, (ii) taxonomy and identification, (iii) distribution and abundance patterns, (iv) parasites, (v) life-history, (vi) feeding ecology, (vii), genetic connectivity (viii) paleontology, (ix) climate change, (x) contaminants, (xi) spatial ecology, and (xii) tourism. To examine spatial and temporal trends in chondrichthyan studies, we analyzed the location of the study (Pacific and Caribbean coast; Cocos Island) and the frequency of publications per year (year/topic). For each study, we also determined the conservation status of target species based on the IUCN Red List criteria (IUCN, 2017).

\section{RESULTS AND DISCUSSION}

\section{Chondrichthyan Diversity}

There are 99 chondrichthyan species formally recorded in the literature and/or with voucher specimens collected within Costa Rican waters (see Table 1 and Appendix I in Supplementary Material). These species are grouped in 2 subclasses (Holocephali and Elasmobranchii), 12 orders, 34 families, and 50 genera. The subclass Holocephali (chimeras) is represented by six species and there are 93 species included in the subclass Elasmobranchii (sharks and rays). Two orders of elasmobranchs, Carcharhiniformes (ground sharks), and Myliobatiformes (stingrays), have the largest number of species within Costa Rican waters, with 27 species each (see Table 1). From these, Carcharhinidae (requiem sharks) and Urotrygonidae (round rays) are the most diverse families, with 16 and 7 species, respectively. A complete list of the formally recorded chondrichthyan species from Costa Rica, as well as additional information on their distribution and habitat preferences, is provided in Appendix I in Supplementary Material.
TABLE 1 | Diversity and distributional patterns of Costa Rican Chondrichthyans.

\begin{tabular}{|c|c|c|c|c|c|c|}
\hline \multirow[t]{2}{*}{ Subclass Order } & \multicolumn{3}{|c|}{ Pacific Ocean } & \multicolumn{3}{|c|}{ Caribbean Sea } \\
\hline & C & $\mathbf{E}$ & $\mathbf{T}$ & C & $\mathbf{E}$ & $\mathbf{T}$ \\
\hline Elasmobranchii & 81 & 11 & 92 & 24 & 81 & 105 \\
\hline Carcharhiniformes & 26 & 4 & 30 & 10 & 26 & 36 \\
\hline Heterodontiformes & 1 & 2 & 3 & 0 & 0 & 0 \\
\hline Hexanchiformes & 0 & 1 & 1 & 1 & 2 & 3 \\
\hline Lamniformes & 6 & 1 & 7 & 1 & 5 & 6 \\
\hline Myliobatiformes & 22 & 2 & 24 & 5 & 10 & 15 \\
\hline Orectolobiformes & 2 & 0 & 2 & 2 & 0 & 2 \\
\hline Rajiformes & 5 & 1 & 6 & 1 & 21 & 22 \\
\hline Rhinopristiformes & 7 & 0 & 7 & 3 & 0 & 3 \\
\hline Squaliformes & 5 & 0 & 5 & 0 & 11 & 11 \\
\hline Squatiniformes & 2 & 0 & 2 & 0 & 1 & 1 \\
\hline Torpediniformes & 5 & 0 & 5 & 1 & 5 & 6 \\
\hline Holocephali & 6 & 1 & 7 & 0 & 6 & 6 \\
\hline Chimaeriformes & 6 & 1 & 7 & 0 & 6 & 6 \\
\hline Total & 87 & 12 & 99 & 24 & 87 & 111 \\
\hline
\end{tabular}

Number of species with confirmed (C), expected (E), and total records ( $T$; confirmed plus expected) in both Pacific and Caribbean Costa Rican waters.

\section{Distribution Patterns and Habitat Preferences}

Of the total number of chondrichthyan species formally reported in Costa Rican waters (99 species), $88 \%$ are known to occur in the Pacific Ocean and $24 \%$ in the Caribbean Sea (Table 1). Twelve of these species have been reported on both sides of the Panamanian isthmus (i.e., there are anfiamerican species). The number of species reported for the Costa Rican Pacific represents $\sim 58 \%$ of the total number of species known to occur in the North Eastern Pacific Ocean (i.e., 151 species, sensu Weigmann, 2016); whereas the number of species reported for the Caribbean Sea represents about $11 \%$ of the total number of species known to occur in the North Western Atlantic Ocean (i.e., 216 species, sensu Weigmann, 2016). Such discrepancies reflect considerable differences in the sampling effort as well as the relative lack of basic and applied studies assessing the species richness and population status of chondrichthyans in Costa Rica, particularly in the Caribbean Sea (Bussing and López, 2009).

All chondrichthyan species known to occur in Costa Rica show marine habits, $39 \%$ are found in both marine and estuarine/brackish environments, and only $4 \%$ have some affinity to freshwater environments (Appendix I in Supplementary Material). Most species (54\%) are restricted to shallow waters (i.e., 0-200 $\mathrm{m}$ depth); 6 of which can also be found in waters deeper than $1000 \mathrm{~m}$. Twenty-eight species are usually found at depths between 0 and $1000 \mathrm{~m}$ (Appendix I in Supplementary Material). The remaining 18 species are restricted to deep waters, with 16 species usually found between 200 and $1000 \mathrm{~m}$, and 2 species restricted to waters deeper than $1000 \mathrm{~m}$. Interestingly, most of these deepwater species (10 species) were formally reported for Costa Rica within the last 4 years (2014-2017), 
three of which were formally described (they represented newly discovered species) during this same period from type specimens collected in Costa Rica (Chimaera orientalis Angulo et al., 2014; Etmopterus benchleyi Vásquez et al., 2015; and Notoraja martinezi Concha et al., 2016). The increase in the number of recently described deep water species in Central America suggests that chondrichthyan richness may increase as research efforts in the region continue.

Coastal chondrichthyans represent $\sim 92 \%$ of the formally reported species (79 species in the Pacific and 21 in the Caribbean). Seventy-one of these coastal species are restricted to inshore and/or continental shelf habitats (i.e., there are "obligate" inshore species) and 20 are both inshore (coastal) and offshore (oceanic) species (Appendix I in Supplementary Material). The remaining eight species are "obligate" offshore species, and all of them are present in the Pacific, whereas only three are present in the Caribbean. Pelagic species represent $\sim 47 \%$ (43 species in the Pacific and 15 in the Caribbean), whereas $81 \%$ exhibit demersal habits (69 species in the Pacific and 18 in the Caribbean; Appendix I in Supplementary Material).

Approximately $35 \%$ of the reported species are known to use or depend, in greater or lesser extent, on reef environments ( 31 species in the Pacific and 9 in the Caribbean), whereas $78 \%$ are typically found in "muddy" (estuaries and mangroves) environments (65 species in the Pacific and 19 in the Caribbean; Appendix I in Supplementary Material). These findings highlight the importance of estuarine and reef habitats to chondrichthyans, either as nursery, reproductive, and/or feeding grounds. However, these inshore habitats are also the most susceptible to human degradation and climate change (Wehrtmann and Cortés, 2009; Jones and Cheung, 2017).

\section{Broad Biogeographic Relationships}

Most chondrichthyan species reported for Costa Rica have wide geographical distribution ranges. Forty-eight species are endemic to the ETP; 24 species are circumglobal; 7 species are endemic to the Western Atlantic Ocean; 6 species have distributions that include the entire Indo-Pacific Ocean; 4 species have distributions on the entire Atlantic Ocean; 4 species are found in both the Eastern Pacific and Western Atlantic Oceans; 3 species are reported for the entire Pacific Ocean; and one species is known to occur in both Atlantic and southwest Indian Oceans (Appendix I in Supplementary Material). In the ETP, Costa Rica represents the northern limit of the distribution range for a total of 7 species [i.e., Chimaera orientalis; Gymnura crebripunctata (Peters 1869); Notoraja martinezi; Squatina armata (Philippi 1887); Tetronarce peruana (Chirichigno, 1963); Tetronarce tremens (de Buen, 1959); and Urobatis pardalis (Del Moral-Flores et al., 2015a)], and also represents the southern distribution limit for the spotted ratfish Hydrolagus colliei (Lay and Bennett, 1839) and the denticled round ray Urotrygon cimar (López and Bussing, 1998; Angulo et al., 2014; Robertson and Allen, 2015).

\section{Expected Species Richness}

Given the current distribution of chondrichthyans in the Pacific and Atlantic coastlines of Latin America, $\sim 182$ species are expected to occur in Costa Rican waters, which means an increase of $84 \%$ in the total number of reported species. Based on these estimations, Costa Rica would have $\sim 66$ and $51 \%$ of the chondrichthyan diversity reported in the North-Eastern Pacific and North Western Atlantic Oceans, respectively (Weigmann, 2016). These values would be more in line with the actual expectations of chondrichthyan diversity in this region, similar to reports for reef and coastal fish assemblages (Bussing and López, 2009; Robertson and Allen, 2015; Robertson and Van Tassell, 2015). The large discrepancy between expected and reported species known to occur in Costa Rica reflect the need for a profound reassessment of the diversity, geographical distribution, and habitat use patterns of chondrichthyans, both at local and regional scales. Research on poorly studied environments such as open waters and the deep sea remains a priority.

\section{Conservation Status}

Fifteen chondrichthyan species reported for Costa Rica are threatened with extinction (Table 2). The lesser electric ray Narcine bancroftii (Griffith and Smith, 1834), the smalltooth sawfish Pristis pectinata (Latham, 1794), and the largetooth sawfish Pristis pristis (Linnaeus, 1758) are listed as "Critically Endangered," whereas the Scalloped hammerhead Sphyrna lewini (Griffith and Smith, 1834) and the great hammerhead Sphyrna mokarran (Rüppell, 1837) are listed as "Endangered" based on the IUCN Red List (IUCN, 2017). The remaining 11 species are listed as "Vulnerable" (see Table 2; IUCN, 2017). In addition, 23 chondrichthyan species are listed as "Near Threatened" (i.e., they may become endangered in the near future) and 11 species are listed as "Least Concern" (i.e., they are widespread and abundant, with a lower risk to become endangered in the near future). What is most concerning, however, is that $41 \%$ of the species known to occur in Costa Rica are "Data Deficient" (i.e., inadequate information to assess a species extinction risk based on distribution and population status) (Table 2), which could mean that the number of threatened species may be greater than expected. This highlights the need to generate information on "Data Deficient" species that may help assess their population status.

TABLE 2 | Conservation status of Costa Rican Chondrichthyans.

\begin{tabular}{lcccccccc}
\hline IUCN Red list category & \multicolumn{3}{c}{ Pacific Ocean } & & \multicolumn{3}{c}{ Caribbean Sea } \\
\cline { 2 - 4 } & C & E & T & & C & E & T \\
\hline Critically endangered & 1 & 0 & 1 & & 3 & 0 & 3 \\
Endangered & 2 & 0 & 2 & & 0 & 3 & 3 \\
Vulnerable & 11 & 4 & 15 & & 3 & 12 & 15 \\
Near Threatened & 20 & 2 & 22 & & 9 & 10 & 19 \\
Least concern & 11 & 1 & 12 & & 21 & 22 \\
Data deficient & 33 & 5 & 38 & & 8 & 40 & 48 \\
Not listed & 9 & 0 & 9 & & 0 & 3 & 3
\end{tabular}

Number of species with confirmed $(C)$, expected $(E)$, and total records (T; confirmed plus expected) in both Pacific and Caribbean Costa Rican waters based on the IUCN (International Union for Conservation of Nature) Red list category (IUCN, 2017). 


\section{Studies on Chondrichthyans in Costa Rican Waters}

Based on our literature search, the total number of publications ( $n=121)$ on chondrichthyans increased in the mid 1990s; only two studies were published before 1960 (Figure 2). Interestingly, after 2008 the number of studies doubled $(n=70)$, highlighting the growing interest in this group. Three-quarters of studies were scientific publications, $11 \%$ books, $9 \%$ theses, and 5\% official technical reports. Only five of the 10 theses published in Costa Rica focused on sharks, rays, or chimeras; the remaining ones only mentioned or included species lists. Most books $(n=10)$ were published as identification guides with general descriptions of common elasmobranch species.

About half of the studies analyzed were on elasmobranchs ( $37 \%$ on sharks, $12 \%$ on rays), and less than $1 \%$ on chimeras. Only $72 \%$ of these studies were conducted in Costa Rican waters ( $n=87$ ), whereas $28 \%$ were part of regional or global-scale assessments. Elasmobranchs have been studied more intensively in the Pacific than in the Caribbean (Table 3). Only three studies focused on chimeras. Most studies from the Pacific of Costa Rica were conducted in Isla del Coco (an isolated volcanic island $\sim 500 \mathrm{~km}$ from Puntarenas; see Figure 1) and the Golfo de Nicoya, a large and highly productive tropical estuary located in the central Pacific. This could be attributed to the biological importance of Isla del Coco as a marine biodiversity hotspot, a World Heritage site and a center of endemism in the ETP (Wehrtmann and Cortés, 2009), as well as to the ecological and economic importance of the Golfo de Nicoya in terms of fisheries and food security (Nielsen Muñoz and Quesada Alpízar, 2006; Wehrtmann and Cortés, 2009).

In Costa Rica, chondrichthyan studies have followed three major research areas: (i) fisheries, (ii) taxonomy, and (iii) distribution patterns (Figure 3). These areas accounted for 75 studies (62\% of the total number of studies analyzed). Fisheries was the category with most studies $(n=28)$, and they generally focused on relatively short-term $(<10$ year $)$ surveys of the elasmobranch by-catch associated with coastal (López-Garro et al., 2009; López-Garro and Zanella, 2015; Clarke et al., 2016) and pelagic fisheries (Whoriskey et al., 2011; Dapp et al., 2013),

TABLE 3 | Number of studies on chondrichthyan fishes conducted in Costa Rican waters $(n=87)$.

\begin{tabular}{lccccc}
\hline Region & $\begin{array}{c}\text { Scientific } \\
\text { publications }\end{array}$ & Books & Theses & $\begin{array}{c}\text { Technical } \\
\text { reports }\end{array}$ & Total \\
\hline Pacific Ocean & 54 & 5 & 8 & 4 & 71 \\
Entire Coast & 11 & 3 & 3 & 4 & 21 \\
Cocos Island & 16 & 2 & 0 & 0 & 18 \\
North Pacific & 5 & 0 & 0 & 0 & 5 \\
Central Pacific & 14 & 0 & 3 & 0 & 17 \\
South Pacific & 8 & 0 & 2 & 0 & 10 \\
Caribbean Sea & 12 & 2 & 1 & 0 & 15 \\
\hline Total & 66 & 7 & 9 & 4 & 85 \\
\hline
\end{tabular}

This list excludes any regional and global-scale study. as well as illegal fishing activities inside MPAs (Arias and Pressey, 2016; López-Garro et al., 2016). Taxonomical studies, including species descriptions and new records within Costa Rica waters were also an important category (Angulo et al., 2014; Del MoralFlores et al., 2015a,b; Concha et al., 2016). This reinforces the need to conduct basic taxonomic studies that may increase the existing chondrichthyan diversity in these waters. Approximately $31 \%$ of the reviewed studies included categories as diverse as parasites $(n=11)$, life-history traits $(n=8)$, feeding ecology $(n=7)$, connectivity $(n=6)$, and paleontology $(n=5)$. Chondrichthyan studies evaluating tourism, spatial ecology, contaminants, and climate change were underrepresented, and accounted for less than $8 \%$ (Figure 3).

Our review highlighted the lack of studies on deep water $(>1000 \mathrm{~m})$ and Caribbean chondrichthyan populations. Given the increasing exploitation of deep water resources (Wehrtmann et al., 2012; Clarke et al., 2016), there are some concerns over the ability of chondrichthyans to sustain high fishing levels in these environments (Simpfendorfer and Kyne, 2009). Similarly, less effort has been given to study Caribbean chondrichthyans in Costa Rica, where reported landings account for less than 4\% of national landings (Fournier and Fonseca, 2007). Therefore, if more landings data are collected from the Caribbean and/or deep-water fisheries, they may revealed previously unrecorded species and conservation priorities.

\section{Chondrichthyan Fisheries in Costa Rica}

Fishing is perhaps the most significant and widespread threat affecting chondrichthyans in Costa Rica (Whoriskey et al.,

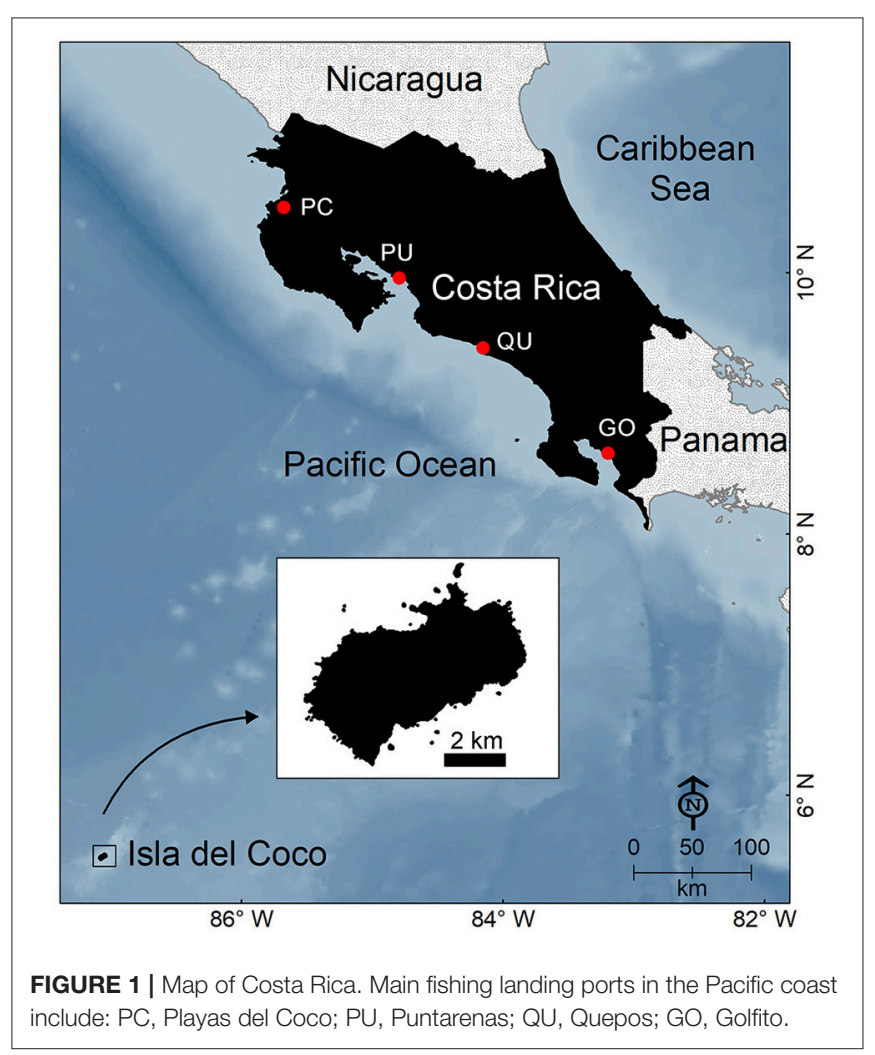




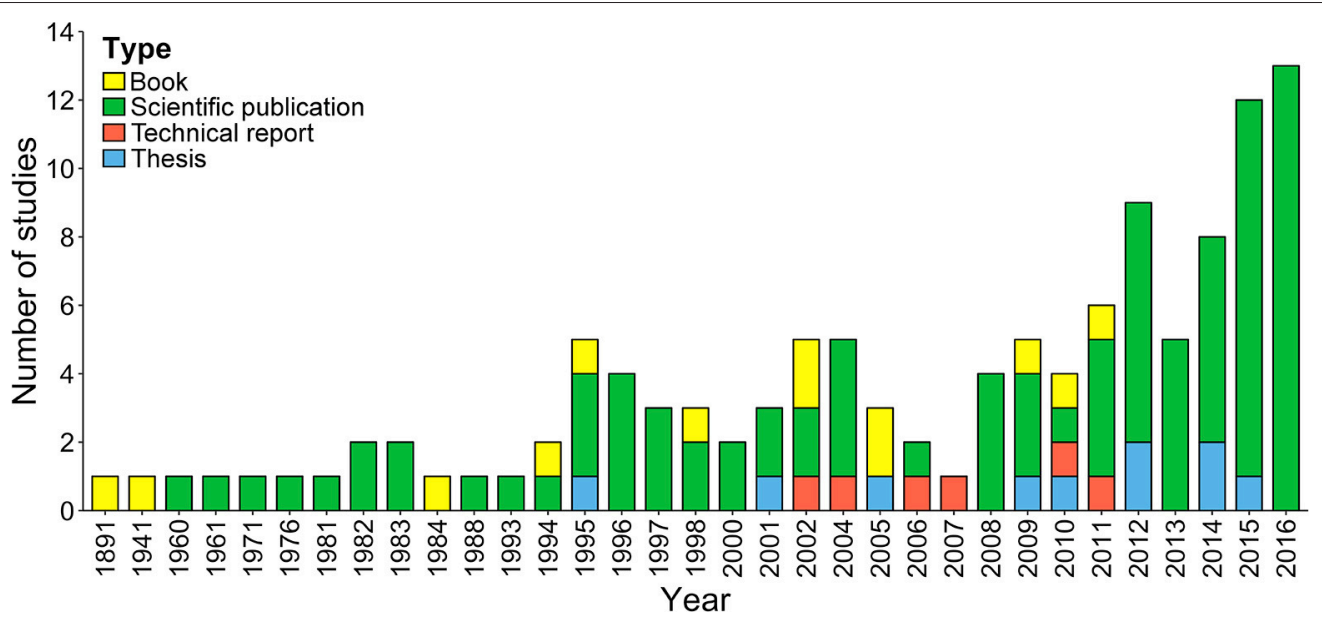

FIGURE 2 | Number and type of studies published on Chondrichthyan fishes in Costa Rica.

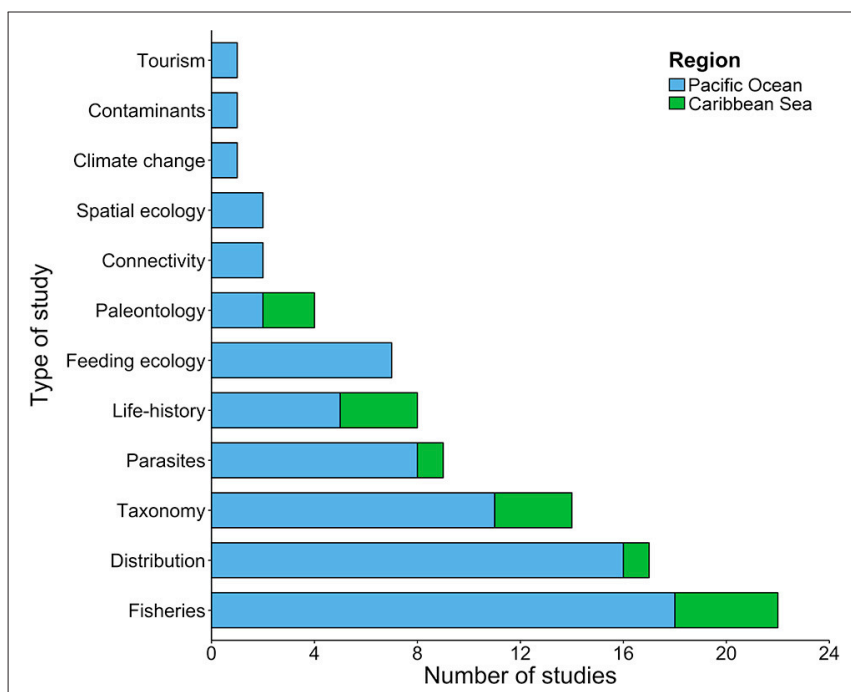

FIGURE 3 | Number of studies (scientific publications, theses, technical reports, and books) by topic conducted in the Pacific Ocean and Caribbean Sea of Costa Rica.

2011; Dapp et al., 2013; Davidson et al., 2016), as the unique life-history traits of some species, poor landing statistics and limited enforcement make them particularly vulnerable to overexploitation (Frisk et al., 2005; Arias et al., 2014; Trujillo et al., 2015). In Costa Rica, small-scale (e.g., gillnet and bottom long-line fisheries) and shrimp trawl fisheries catch a large number of sharks and rays in coastal environments (HerreraUlloa et al., 2011; Clarke et al., 2016, 2017). In contrast, pelagic longline and purse seine fisheries catch several shark species in the open ocean as their main target or as bycatch (Rojas et al., 2000; Arauz et al., 2007). While coastal fisheries capture chondrichthyans with a wide range of sizes and life history strategies, pelagic fisheries tend to catch larger, more vulnerable species (Whoriskey et al., 2011; Dapp et al., 2013) (Figure 4).
The higher proportion of threatened species in pelagic fisheries may result from differences in gear selectivity and the decline of top predators from coastal waters. Moreover, the number of threatened species caught by coastal fisheries may be higher than current assessments indicate due to the large proportion of batoids and carcharhinids categorized as "Data Deficient" (Figure 4).

\section{Small-Scale Fisheries (SSF)}

In Costa Rica, SSF are highly dynamic, with both spatial and temporal variations in fishing effort along the coastline (Salas et al., 2007; Araya, 2013). These fisheries operate mainly in the Pacific and land up to 20 species of sharks and rays (Figure 4), some of which are targeted during reproductive aggregations and in nursery grounds (López-Garro et al., 2009; López-Garro and Zanella, 2015; Clarke et al., 2017). Shark catches in SSF are an important source of low-cost protein for the national consumer market (Herrera-Ulloa et al., 2011). Therefore, SSF have the potential to greatly impact many elasmobranchs, as documented by Amador (2010) who found that catches of longtail stingray Hypanus longus (Garman, 1880) declined by $60 \%$ between 2005 and 2007. Moreover, since the early 2000s, declines in shark meat landings drove an increase in shark meat imports from Belize, Taiwan, and Panama (Dent and Clarke, 2015).

\section{Pelagic Fisheries}

Pelagic fleets operate mainly in the Pacific Economic Exclusive Zone (EEZ) of Costa Rica, targeting mahi-mahi, swordfish, and large pelagic sharks with longlines and purse seines (Rojas et al., 2000; Arauz et al., 2007; Whoriskey et al., 2011; Dapp et al., 2013). These fisheries land up to 35 species of sharks and rays (Figure 4). Between 1988 and 1997 pelagic sharks represented over $20 \%$ of the national landings volume (Rojas et al., 2000; Bonilla and Chavarría, 2004), while shark catch rates declined over 60\% (Kyne et al., 2012; Dapp et al., 2013). Similarly, the 


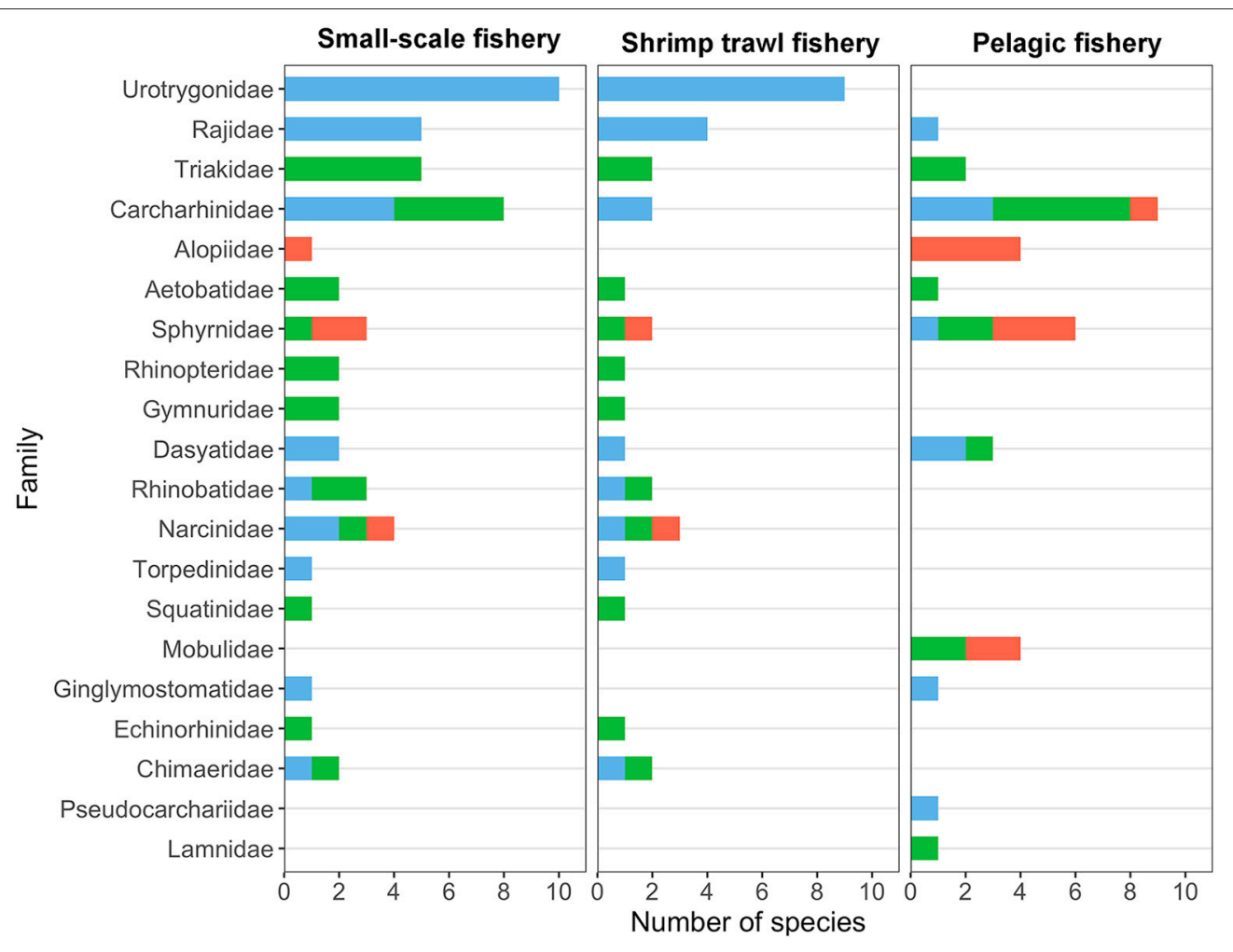

Data Deficient Not threatened Threatened

FIGURE 4 | Number of species per family captured by small-scale, trawl, and pelagic fisheries in Costa Rica. Data deficient and not assessed species are represented in blue, non-threatened species are represented in green and threatened species are represented in red (IUCN Red List categories). Species catch data were obtained from the following studies: Arauz et al. (2007), Benavides et al. (2014), Bystrom (2015), Campos (1986), Clarke et al. (2016), Dapp et al. (2013), López-Garro et al.

(2009), López-Garro and Zanella (2015), Rojas et al. (2000), and Whoriskey et al. (2011).

abundance of S. lewini at Isla del Coco declined by $\sim 45 \%$ between 1993 and 2013 (White et al., 2015).

Most sharks caught in pelagic fisheries are exported, and therefore, trends in exportation records may provide additional information about pelagic shark fisheries. During 2000-2011, Costa Rica was the sixth largest exporter of shark meat products, the eighth largest exporter of shark fins in terms of volume, and seventh in terms of value (Dent and Clarke, 2015). Between 2000 and 2011, Canada, China, Hong Kong, Indonesia, Malaysia, Singapore, and Taiwan imported an average of 8.9 million USD in shark fins a year from Costa Rica (Dent and Clarke, 2015). However, Costa Rica only reported an average export of 1.9 million USD in shark fins during the same period. After 2011, Costa Rica fell from the sixth largest exporter to the 28th due to declining catches (Dent and Clarke, 2015). There are large discrepancies between the landings and exports recorded by the national fishery agency and FAO estimates (Figure 5), yet, the factors driving these discrepancies remain uncertain and require further attention (Dent and Clarke, 2015; Trujillo et al., 2015).

The foreign pelagic fleet has the highest fishing capacity and usually targets mahi-mahi, swordfish, and sharks (Siu and AiresDa-Silva, 2016). From 2004 to 2010, an average of 36 foreign vessels from China, Cambodia, Indonesia, Panama, Georgia, and the United States landed their catch in Costa Rica (Siu and Aires-Da-Silva, 2016). Siu and Aires-Da-Silva (2016) reported that due to increased regulations, foreign vessels have not landed in Costa Rica since 2015. However, the lack of information on landings in private docks and fishing effort in the open seas makes it unclear whether foreign fishing vessel activity has actually stopped (Dent and Clarke, 2015). Moreover, it is also important to consider that there may be foreign fishing fleets that operate within Costa Rican waters, but land their catch elsewhere. Automatic Identification Systems (AIS) tracking data is being increasingly used to detect illegal fishing, transshipments and fisheries dynamics, and therefore, represent a powerful management tool that may strengthen the conservation of shark species in the ETP (Robards et al., 2016; Kroodsma et al., 2017; White et al., 2017).

\section{Trawl Fisheries}

Shallow and deepwater bottom trawl fisheries also operate mainly in the Pacific, catching 34 species of elasmobranchs as bycatch (Figure 4) (Clarke et al., 2016). Although shark and ray bycatch is not recorded, catch reconstructions estimate that a total of 7.7 tons of bycatch were caught per ton of shrimp between 1950 and 2010, 85\% of which was discarded (Trujillo et al., 2015). 

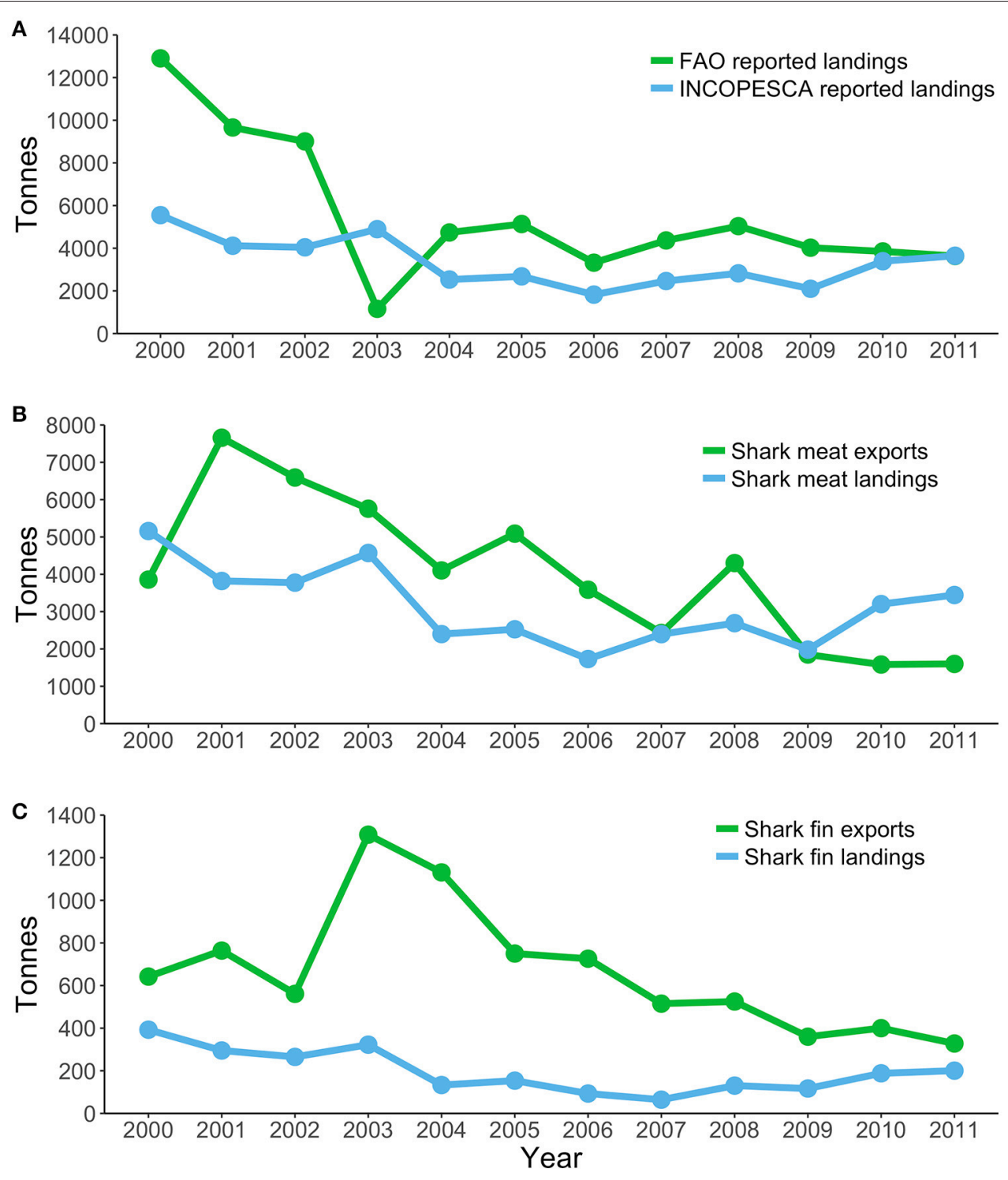

FIGURE 5 | Fisheries landings and exports of shark products in Costa Rica during 2000-2011. (A) Landings reported by FAO and landings reported by the Costa Rican Fishing Institute (INCOPESCA). (B) Shark meat exports reported by Dent and Clarke (2015) and shark meat landings (INCOPESCA). (C) Shark fin landings estimated by Dent and Clarke (2015) and shark fin landings (INCOPESCA).

Large, slow moving demersal species are the most susceptible to bottom trawling, with the brown smoothhound Mustelus henlei (Gill, 1863), velez ray Rostroraja velezi (Chirichigno F. 1973), southern banded guitarfish Zapteryx xyster (Jordan and Evermann, 1896), and panamic stingray Urotrygon aspidura (Jordan and Gilbert, 1882) comprising over $70 \%$ of catches from 2008 to 2012 (Clarke et al., 2016). At a population level, a recent ecological risk assessment revealed that S. lewini, the prickle shark Echinorhinus cookei (Pietschmann, 1928) and H. longus were the most vulnerable elasmobranch species (Clarke et al., 2017). However, Clarke et al. (2016) found these species were no longer an abundant component of the elasmobranch bycatch in recent years (2008-2012).

\section{Management Challenges Data Deficiency}

A common issue that challenges fisheries management in the ETP is the poor quality and quantity of landing statistics and catch-effort data (Salas et al., 2007). In Costa Rica, for example, if recorded, landings are typically grouped into broad commercial categories that do not allow us to detect trends even at broad taxonomic levels such as "shark," "ray," or "elasmobranch" (CGR, 2007). Factors that hinder the collection of adequate landings statistics vary among fisheries. In SSF, there are not enough inspectors to record landings at all the small landing sites scattered across the entire coastline (Salas et al., 2007). Moreover, a high percentage of catches do not enter the commercial 
value chain because they are consumed locally, used as bait or discarded (Salas et al., 2007). In contrast, landings from pelagic fisheries are concentrated in four main ports (Figure 1), where inspectors from the Costa Rican fishing institute regularly monitor shark landings. However, the collection of catch/effort data is hampered by the a lack of onboard observers, distant fishing grounds, long fishing trips, illegal fishing, high-grading, and discarding (Rojas et al., 2000; Arauz et al., 2007; López-Garro et al., 2016).

In countries like Costa Rica, the costs associated with the management and data collection for SSF would exceed the value of the catch, and therefore, traditional approaches may not be feasible (Salas et al., 2007). In this case, participatory landings data collection should be deployed in coastal fisher communities to develop extrapolated catch figures for SSF using total effort estimates (e.g., number of fishers). Engaging fisher communities in landings data collection may also be a transparent and socially responsible way to raise local capacity, contribute to decision making and in the process of adaptive management. Large revenues generated from pelagic fisheries could be used to offset costs of deploying these SSF processes and allow the creation of artisanal coastal fisheries management plans.

Data deficiency in national large-scale pelagic fisheries can be offset through the collection and analysis of information by regional fisheries management organization such as the InterAmerican Tropical Tuna Commission (IATTC) (IATTC, 2016; Griffiths et al., 2017). Given the wide-ranging nature of pelagic sharks within the ETP, targeted species and/or populations may benefit from a regional approach to data collection, analysis, and management. For instance, a recent ecological risk assessment conducted by the IATTC revealed that 13 of the 18 highly vulnerable species were sharks (Griffiths et al., 2017). Yet, management measures have only been implemented for the silky shark Carcharhinus falciformis (Müller and Henle, 1838) and devil rays Mobula spp. (IATTC, 2016), highlighting the need to improve management actions for many species that are currently at risk.

\section{Weak Fisheries Management Framework}

Although the existing statistical and biological information is not sufficient to adequately assess the status of many of the chondrichthyan stocks within the ETP, scientific, and traditional ecological knowledge indicate that shark landings in this region are decreasing while fishing effort is increasing (Whoriskey et al., 2011; Kyne et al., 2012; Dapp et al., 2013; Dent and Clarke, 2015). Declines in shark landings have led to concerns over the impacts of fisheries on shark populations within the ETP (Arauz et al., 2007; Whoriskey et al., 2011; Clarke et al., 2017). Identified drivers of overfishing include corruption and conflicts of interest within the fisheries management agency, weak management frameworks, fleet overcapacity, lack of enforcement, and illegal fishing activities (CGR, 2007; Arias and Pressey, 2016).

In Costa Rica the industrial fishing sector has a majority representation on the board of directors in charge of fisheries management, potentially driving private interests. Moreover, a lack of resources and capacity severely hinder the implementation of existing fisheries management legislation.
NGOs and environmental government organizations, however, have allowed the development of sustainable fisheries projects, and raise awareness about shark finning and illegal fishing in MPAs.

\section{Lack of Enforcement of International Regulations}

Implementation is also an issue with international treaties ratified by Costa Rica, such as CITES and CMS (Convention on the Conservation of Migratory Species of Sharks), which promote the protection and conservation of threatened elasmobranch species (Davidson et al., 2016). At least six threatened shark species ( $S$. lewini, S. zygaena, S. mokarran, C. longimanus, C. falciformis, and Alopias pelagicus) currently exported from Costa Rica to Hong Kong are regulated by Appendix II of the CITES (Davidson et al., 2016). Moreover, both Pristis pristis and P. pectinata are included in Appendix I of CITES, which prohibits the extraction and international trade of specimens. However, there is evidence that shark fin traders are still exporting mislabeled and unidentified shark fins, including those of prohibited species (Abercrombie and Hernandez, 2017). Therefore, illegal shark trade could be reduced by increasing the transparency along the chain of custody for shark products. Building capacities to identify and quantify elasmobranch products throughout the supply chain is also imperative to enforce and comply with national and international regulations (Abercrombie and Hernandez, 2017).

\section{Management and Research Needs Adaptive Management Framework}

From a biological standpoint, there are many information gaps that must be filled to better guide management and conservation efforts in Costa Rica and other data-poor countries from the ETP. Although the road ahead may seem overwhelming, a useful starting point might be to identify vulnerable species through data-poor ecological risk assessments and implement precautionary management measures. Subsequently, a monitoring program should be established to assess the effectiveness of these management actions in reaching previously defined management targets (Figure 6).

An adaptive management blueprint for a data-poor situation can be illustrated by the Costa Rican shrimp trawl fishery. A recent risk assessment identified S. lewini as one of the most vulnerable bycatch species (Clarke et al., 2017). Based on our knowledge of the interaction of S. lewini with coastal and pelagic fisheries, precautionary measures should (i) regulate and/or ban the use of coastal gillnets during pupping/breeding seasons (López-Garro et al., 2009; Zanella and López-Garro, 2015), and (ii) reduce fishing effort offshore, particularly during adult reproductive migrations (Zanella and López-Garro, 2015). Catch and effort should then be monitored to evaluate fisheries impact on population trends (Figure 6).

\section{Addressing the Social and Economic Incentives of Overfishing}

Fishing effort should be reduced by addressing the root causes of overcapacity, which in SSF are the marginalization and displacement of coastal communities (Pauly, 1990; Fargier et al., 2014). In the 1980s, agrarian reforms displaced farmers from 


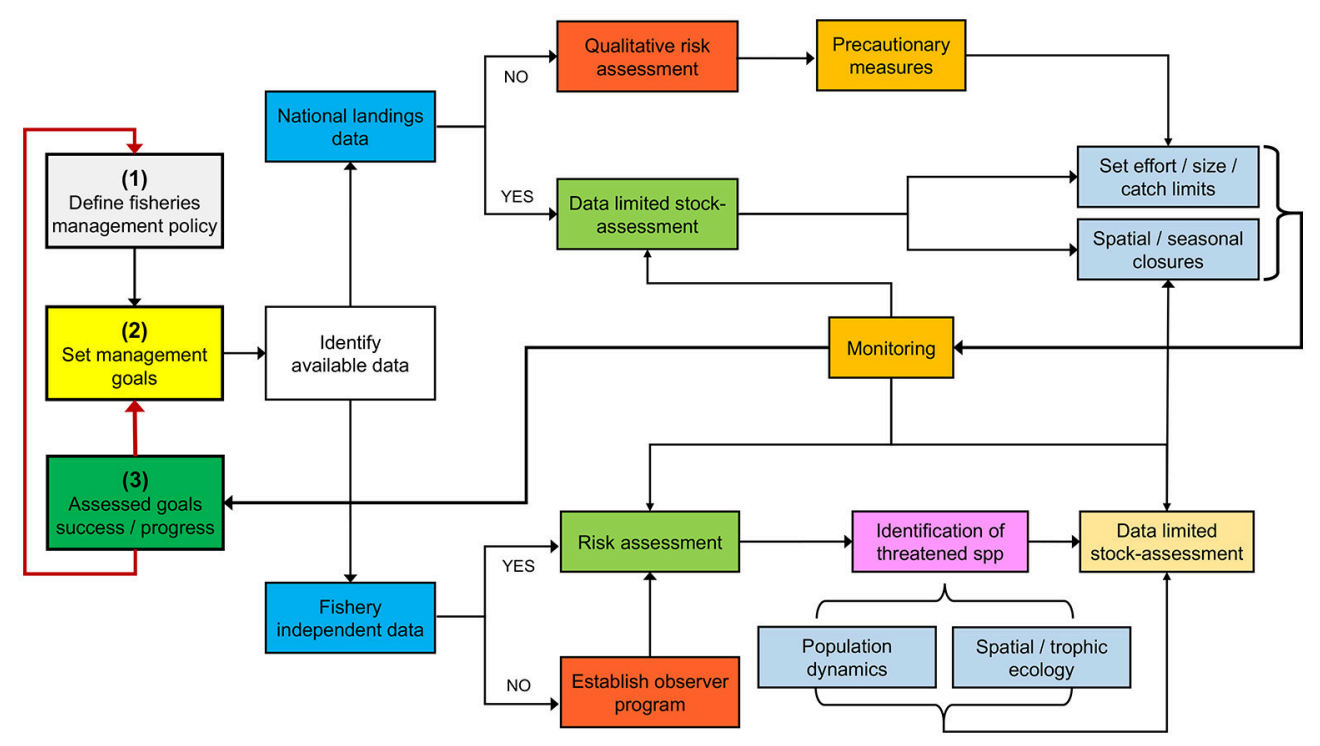

FIGURE 6 | Adaptive management framework for data-deficient fisheries using Costa Rica as a case study.

their lands and forced them to settle along the coastline, where fishing was the main source of employment. Fishing effort increased, placing even more pressure on already depleted resources (Fargier et al., 2014). Therefore, increasing social wellbeing and employment opportunities in coastal communities should reduce pressure on coastal stocks. In industrial fisheries, diesel subsidies and weak management frameworks are the root causes of overfishing, consequently, the elimination of these subsidies may reduce profitable fishing effort, allowing some stocks to recover (Clark et al., 2005; Sumaila et al., 2008).

\section{Generating Life-History Data}

Given the increasing fishing pressure on chondrichthyans populations in the ETP, generating species-specific life-history information (age/growth, maturity, and fecundity) is a crucial step toward informing fisheries management and conducting reliable stock assessments. In Costa Rica, some studies have examined the distribution, reproduction and diet of demersal and/or coastal elasmobranchs associated with SSF from the Pacific (Zanella Cesarotto et al., 2010; Clarke et al., 2014, 2016; Espinoza et al., 2015b; Zanella and López-Garro, 2015), providing critical life-history information on threatened and data deficient species, as well as identifying reproductive seasons and critical areas along the coast that may function as nursery, breeding and feeding grounds. This type of work is important to adequately manage fisheries impacts on coastal chondrichthyans, thus facilitating the design and implementation of effective spatial and temporal closures (Rojas, 2006; Clarke et al., 2014; Zanella and López-Garro, 2015).

\section{Application of Genetic Markers}

The use of genetic markers in fisheries management and conservation has resulted in significant insights into the population ecology of exploited chondrichthyan species
(Dudgeon et al., 2012). Numerous studies have revealed different levels of connectivity on a wide range of shark species that occur within Costa Rican waters (Nance et al., 2011; Galván-Tirado et al., 2013; Cardeñosa et al., 2014; Chabot et al., 2015), providing strong evidence that coastal and pelagic shark populations are not limited to a single EEZ. These findings support the need for regional management approaches that may improve the conservation and/or sustainability of chondrichthyan species. The use of DNA barcoding has also proven to be a valuable approach to identify common elasmobranch species associated with the domestic (O'Bryhim et al., 2017) and international (Shivji et al., 2005) Costa Rican trade. Moreover, several shark species have been morphologically and genetically identified from shark fin exports (e.g., C. longimanus, and S. lewini) (Abercrombie and Hernandez, 2017), proving a useful tool to enforce domestic and international regulations. This is particularly important given that six shark species from Costa Rica are listed on the Appendix II of CITES (Convention on International Trade in Endangered Species of Fauna and Flora).

Given the low number of genetic studies on chondrichthyan species within Costa Rican waters, determining the population structure, philopatric behavior, and local adaptation processes remains crucial. Moreover, the emergence of novel techniques such as eDNA allow researchers to monitor cryptic and/or threatened elasmobranch species based on traces of their DNA found in the environment (Simpfendorfer et al., 2016; Thomsen et al., 2016; Bakker et al., 2017). Therefore, the use of eDNA may be a relatively cost-effective technique to monitor critically endangered species such as sawfishes (P. pristis and $P$. pectinata) within continental waters of Central America and/or conduct regional-scale assessments of chondrichthyan populations within the ETP (Bakker et al., 2017). 


\section{Trophic Ecology}

High trophic level predators fulfill a variety of ecological roles in both terrestrial and aquatic ecosystems (Terborgh and Estes, 2010). Some sharks, for example, are capable of regulating prey dynamics, structuring marine food webs, and ultimately may help maintain ecosystem function and health (Sergio et al., 2008; Heithaus et al., 2014). Consequently, large-scale population declines of shark species that act as top predators may lead to wide-ranging ecological and economic consequences (Heithaus et al., 2014; Heupel et al., 2014). However, for most chondrichthyans trophic information is scarce and/or the role they play in aquatic ecosystems have not been defined.

Fisheries management has traditionally focused on understanding the population dynamics of target species rather managing fishing impacts on entire ecosystems (Gilman et al., 2008), which requires a deeper knowledge of their trophic ecology. In Costa Rica, feeding studies on elasmobranchs have relied on stomach content analysis (Rojas, 2006; Espinoza et al., 2012, 2013), and only until recently researchers have used stable isotopes to investigate feeding relationships across larger areas (Espinoza et al., 2015b; Sandoval-Herrera et al., 2016). Stable isotopes of carbon $\left(\delta^{13} \mathrm{C}\right)$ and $\left(\delta^{15} \mathrm{~N}\right)$ provide useful long-term integrated dietary information on the movements, habitat use and trophic relationships of elasmobranch species (Hussey et al., 2011, 2012). Therefore, integrating trophic information from stable isotopes with fisheries data is highly relevant to developing sound ecosystem-based management approaches (Kitchell et al., 2002; Gilman et al., 2008), and should be an important emergent research area in the ETP.

\section{Spatial Ecology}

The movement of animals between habitats is a key process that maintains population connectivity, and ultimately persistence (Olds et al., 2012). Understanding when, where, and why animals move and use specific habitats is crucial to conservation and has direct applications to spatial management planning (Espinoza et al., 2015a). Despite the relatively low number of published studies on shark movements within Costa Rican waters (Nalesso, 2014; Calderón-Chávez, 2017), there has been a considerable amount of effort to investigate migratory patterns of threatened species in the ETP region, particularly at offshore/remote MPAs such as Isla del Coco, Islas Galapagos, and Malpelo. Acoustic and satellite tracking data on adult scalloped hammerhead sharks (S. lewini), for example, has provided important information about their degree of residency and inter-island movements within the ETP (Bessudo et al., 2011; Ketchum et al., 2014; Nalesso, 2014). From a management perspective, quantifying how much time $S$. lewini remain at each island (i.e., Isla del Coco, Islas Galapagos, Isla Malpelo), determining when they leave, and identifying potential migratory corridors between these islands is a crucial step to reducing fisheries impacts on their populations. The establishment of large networks of acoustic receivers have also allowed researchers to track the movements of coastal and pelagic species over broad spatial scales (10$1000 \mathrm{~km}$ ) (Cooke et al., 2011; Hussey et al., 2015; Espinoza et al., 2016). For instance, in the ETP region, the network MIGRAMAR is generating critical movement information toward the conservation of a wide range of migratory species as well as their critical habitats (Nasar et al., 2016).

Filling the gaps in elasmobranch spatial ecology (e.g., residency and site fidelity, horizontal and vertical space use, and migratory patterns) is crucial to: (i) quantify the extent of overlap with fisheries operating in the ETP; (ii) identify critical habitats for feeding and reproduction, or potential linkages between ecosystems; (iii) design effective spatial management approaches such as marine reserves or corridors that can increase protection during migration; (iv) evaluate the benefits gained from existing/proposed spatial approaches, particularly for wide ranging species that may only have limited protection; (v) establish or strengthen regional management and conservation approaches to protect cross-boundary species; and (vi) ultimately, define their role in aquatic ecosystems. Movement data on pelagic sharks can also be complemented with information on the spatial distribution of fishing effort (vessel tracking information from both national and international fishing fleets, satellite images) thus increasing our understanding of their degree of spatial and temporal overlap (Queiroz et al., 2016).

\section{Assessing the Effect of Climate-Driven Changes}

Climate-impacts on chondrichthyans are projected to be highest in the tropics, where a decrease in size, abundance, and diversity is expected (Cheung et al., 2012; Jones and Cheung, 2015). Although chondrichthyans may adapt to a changing climate, current studies have already documented pole-wards shifts of tens to hundreds of kilometers for marine species (Block et al., 2011; Hazen et al., 2012). Species with slow growing life history strategies and with high affinity to specific habitats (e.g., coral reefs, mangroves, wetlands) are projected to be the most vulnerable to climate impacts (Chin et al., 2010; Hazen et al., 2012; Waples and Audzijonyte, 2016). To enhance the adaptive capacity of chondrichthyans in the face of these globalscale changes, we need to improve our understanding of species diversity, movement, and distribution patterns.

\section{CONCLUSIONS}

Despite the increasing number of chondrichthyan studies in Costa Rica over the past decade, there is still a need to redirect efforts toward specific research areas, regions, and species (batoids and chimeras) that currently have major information gaps. The Caribbean coast and the deep-sea, for example, are critical regions where landing statistics and basic biological/ecological information of sharks, rays, and chimeras are lacking (Cortés et al., 2012). This review also identified important management challenges and research needs that should be addressed to improve the conservation of Chondrichthyans in Costa Rican waters. For instance, improving the quality and quantity of fisheries landing statistics, as well as the knowledge on chondrichthyans that interact with small-scale coastal and pelagic fisheries remains a priority. We proposed an adaptive management framework for chondrichthyan fisheries in data-poor countries where management goals/targets are clearly defined. Due to the uncertainty inherent in data-poor fisheries, 
applying the precautionary approach to buffer unforeseen impacts on chondrichthyan stocks is needed (Selkoe et al., 2015). This may allow conducting proper risk and/or stock assessments and monitor the success/progress of the management goals, thus strengthening the conservation of chondrichthyan populations in the region.

\section{AUTHOR CONTRIBUTIONS}

$\mathrm{ME}, \mathrm{ED}, \mathrm{AA}, \mathrm{SH}$, and $\mathrm{TC}$ contribute with the literature review, analysis of published data, and writing of the paper.

\section{FUNDING}

This review was funded by the Vicerrectoría de Investigación from the Universidad de Costa Rica (Project No. 808-B7-146).

\section{ACKNOWLEDGMENTS}

The authors would like to thank many of their colleagues for discussions about different aspects of the biology, ecology, and fisheries management of chondrichthyan fishes in Costa Rica and the Central American region that have helped to frame this review. We would like to thank Raquel Romero Chaves for her help with the map in Figure 1. Finally, we also are thankful for the comments from two reviewers that help improve this manuscript.

\section{SUPPLEMENTARY MATERIAL}

The Supplementary Material for this article can be found online at: https://www.frontiersin.org/articles/10.3389/fmars. 2018.00085/full\#supplementary-material

\section{REFERENCES}

Abercrombie, D. L., and Hernandez, S. (2017). Identifying Shark Fins: Implementing Enforcing CITES. Abercrombie \& Fish. Suffolk County, NY: Marine Biological Consulting.

Amador, L. (2010). Descripción y Análisis de la Pesca Artesanal de la Raya Látigo Dasyatis Longa (Myliobatiformes, Dasyatidae) en Tárcoles, Puntarenas, Pacifico de Costa Rica. Tesis de Licenciatura, Universidad Nacional de Costa Rica, Heredia.

Angulo, A., López, M. I., Bussing, W. A., and Murase, A. (2014). Records of chimaeroid fishes (Holocephali: Chimaeriformes) from the Pacific coast of Costa Rica, with the description of a new species of Chimera (Chimaeridae) from the eastern Pacific Ocean. Zootaxa 3861, 554-574. doi: 10.11646/zootaxa.3861.6.3

Arauz, R., López, A., and Zanella, I. (2007). “Informe final: análisis de la descarga anual de tiburones y rayas en la pesquería pelágica y costera del Pacífico de Costa Rica (Playas del Coco, Tárcoles y Golfito)," in Presentado a Conservación Internacional Centroamérica (San José).

Araya, S. S. (2013). Situación actual de la pesca artesanal en Costa Rica. Anu. Estud. Centroam. Univ. Costa Rica 39, 311-342.

Arias, A., and Pressey, R. L. (2016). Combatting illegal, unreported, and unregulated fishing with information: a case of probable illegal fishing in the tropical Eastern Pacific. Front. Mar. Sci. 3:13. doi: 10.3389/fmars.2016.00013

Arias, A., Pressey, R. L., Jones, R. E., Álvarez-Romero, J. G., and Cinner, J. E. (2014). Optimizing enforcement and compliance in offshore marine protected areas: a case study from Cocos Island, Costa Rica. Oryx 50, 18-26. doi: $10.1017 /$ S0030605314000337

Bakker, J., Wangensteen, O. S., Chapman, D. D., Boussarie, G., Buddo, D., Guttridge, T. L., et al. (2017). Environmental DNA reveals tropical shark diversity in contrasting levels of anthropogenic impact. Sci. Rep. 7:16886. doi: 10.1038/s41598-017-17150-2

Benavides, M., R., Brenes, R., C. L., and Márquez, A., A. (2014). Análisis de la población de condrictios (Vertebrata: Chondrichthyes) de aguas demersales y profundas del Caribe centroamericano, a partir de faenas de prospección pesquera con redes de arrastre. Rev. Ciencias Mar. Costeras 6, 9-27. doi: 10.15359/revmar.6.1

Bessudo, S., Soler, G. A., Klimley, A. P., Ketchum, J. T., Hearn, A., and Arauz, R. (2011). Residency of the scalloped hammerhead shark (Sphyrna lewini) at Malpelo Island and evidence of migration to other islands in the Eastern Tropical Pacific. Environ. Biol. Fishes 91, 165-176. doi: 10.1007/s10641-011-9769-3

Block, B. A., Jonsen, I. D., Jorgensen, S. J., Winship, A. J., Shaffer, S. A., Bograd, S. J., et al. (2011). Tracking apex marine predator movements in a dynamic ocean. Nature 475, 86-90. doi: 10.1038/nature10082

Bonilla, R., and Chavarría, J. B. (2004). Box-Jenkins analysis for shark landings in Costa Rica. Rev. Biol. Trop. 52, 183-188.

Bussing, W. A., and López, M. I. (2009). "Marine fish," in Marine Biodiversity of Costa Rica, Central America. Monographiae Biologicae, Vol 86, eds I. S. Wehrtmann and J. Cortés (Dordrecht: Springer), 453-458.

Bystrom, A. (2015). Análisis de Características Biológico-Pesqueras del Pargo Manchado (Lutjanus guttatus (Steindachner, 1869) y Tendencias SocioEcológicas de la Pesca Artesanal Con líneas de Fondo en el Distrito de Bejuco, Pacífico de Costa Rica. Tesis de Maestría, Universidad Estatal a Distancia,. San José.

Calderón-Chávez, E. J. (2017). Movimientos y selección de Hábitat del Tiburón toro (Carcharhinus leucas) en el Estero Coyote, Guanacaste, Costa Rica. Tesis de Maestría, Universidad Nacional del Costa Rica, Heredia.

Campos, J. A. (1986). Fauna de acompañamiento del camarón en el Pacífico de Costa Rica. Rev. Biol. Trop. 34, 185-197.

Cardeñosa, D., Hyde, J., and Caballero, S. (2014). Genetic diversity and population structure of the pelagic thresher shark (Alopias pelagicus) in the Pacific Ocean: evidence for two evolutionarily significant units. PLoS ONE 9:e110193. doi: 10.1371/journal.pone.0110193

Carrier, J. C., Musick, J. A., and Heithaus, M. R. (2010). Sharks and Their Relatives II. Boca Raton, FL: CRC Press.

CGR (2007). División de Fiscalización Operativa y Evaluativa Área de Servicios Públicos Generales y Ambientales. Informe sobre la evaluación de la gestión del INCOPESCA en relación con la vigilancia y control de la pesca del tiburón, San José.

Chabot, C. L., Espinoza, M., Mascareñas-Osorio, I., and Rocha-Olivares, A. (2015). The effect of biogeographic and phylogeographic barriers on gene flow in the brown smoothhound shark, Mustelus henlei, in the northeastern Pacific. Ecol. Evol. 5, 1-16. doi: 10.1002/ece3.1458

Chapman, D. D., Feldheim, K. A., Papastamatiou, Y. P., and Hueter, R. E. (2015). There and back again : a review of residency and return migrations in sharks, with implications for population structure and management. Annu. Rev. Mar. Sci. 7, 547-570. doi: 10.1146/annurev-marine-010814-015730

Cheung, W. W. L., Sarmiento, J. L., Dunne, J., Frölicher, T. L., Lam, V. W. Y., Deng Palomares, M. L., et al. (2012). Shrinking of fishes exacerbates impacts of global ocean changes on marine ecosystems. Nat. Clim. Chang. 3, 254-258. doi: $10.1038 /$ nclimate 1691

Chin, A., Kyne, P. M., Walker, T. I., and McAauley, R. B. (2010). An integrated risk assessment for climate change: analysing the vulnerability of sharks and rays on Australia’s Great Barrier Reef. Glob. Chang. Biol. 16, 1936-1953. doi: $10.1111 / j .1365-2486.2009 .02128 . x$

Chirichigno, F. N. (1963). Nuevas especies de "Rayas" para la fauna del Perú. Lima: Serie de divulgación cientifica/Servicio de Pesquería, Ministerio de Agriculture, 20, 1-13. 
Clark, C. W., Munro, G. R., and Sumaila, U. R. (2005). Subsidies, buybacks, and sustainable fisheries. J. Environ. Econ. Manage. 50, 47-58. doi: 10.1016/j.jeem.2004.11.002

Clarke, T. M., Espinoza, M., Ahrens, R., and Wehrtmann, I. S. (2016). Elasmobranch bycatch associated with the shrimp trawl fishery off the pacific coast of Costa Rica, Central America. Fish. Bull. 114, 1-17. doi: 10.7755/FB.114.1.1

Clarke, T. M., Espinoza, M., and Wehrtmann, I. S. (2014). Reproductive ecology of demersal elasmobranchs from a data-deficient fishery, Pacific of Costa Rica, Central America. Fish. Res. 157, 96-105. doi: 10.1016/j.fishres.2014.04.003

Clarke, T. M., Espinoza, M., Romero-Chavez, R., and Wehrtmann, I. S. (2017). Assessing the vulnerability of demersal elasmobranchs to a data-poor shrimp trawl fishery in Costa Rica, Eastern Tropical Pacific. Biol. Conserv. 217, 321-328. doi: 10.1016/j.biocon.2017.11.015

Concha, F. J., Ebert, D. A., and Long, D. J. (2016). Notoraja martinezi sp. nov., a new species of deepwater skate and the first record of the genus Notoraja Ishiyama, 1958 (Rajiformes: Arhynchobatidae) from the eastern Pacific Ocean. Zootaxa 4098, 179-190. doi: 10.11646/zootaxa.4098.1.9

Cooke, S. J., Iverson, S. J., Stokesbury, M. J. W., Hinch, S. G., Fisk, A. T., VanderZwaag, D. L., et al. (2011). Ocean tracking network Canada: a network approach to addressing critical issues in fisheries and resource management with implications for ocean governance. Fisheries 36, 583-592. doi: 10.1080/03632415.2011.633464

Cortés, J., Sánchez-Jiménez, A., Rodríguez-Arrieta, J. A., Quirós-Barrantes, G., González, P. C., and Blum, S. (2012). Elasmobranchs observed in deepwaters (45-330m) at Isla del Coco National Park, Costa Rica (Eastern Tropical Pacific). Rev. Biol. Trop. 60, 257-273.

Dapp, D., Arauz, R., Spotila, J. R., and O'Connor, M. P. (2013). Impact of Costa Rican longline fishery on its bycatch of sharks, stingrays, bony fish and olive ridley turtles (Lepidochelys olivacea). J. Exp. Mar. Biol. Ecol. 448, 228-239. doi: 10.1016/j.jembe.2013.07.014

Davidson, L. N. K., Krawchuk, M. A., and Dulvy, N. K. (2016). Why have global shark and ray landings declined: improved management or overfishing? Fish Fish. 17, 438-458. doi: 10.1111/faf.12119

de Buen, F. (1959). Notas preliminares sobre la fauna marina preabismal de Chile, con descripción de una familia de rayas, dos géneros y siete especies nuevos. Boletim do Museo Nacional de Chile 7, 171-201.

Del Moral-Flores, L. F., Angulo, A., López, M. I., and Bussing, W. A. (2015a). Nueva especie del género Urobatis (Myliobatiformes: Urotrygonidae) del Pacífico oriental tropical. Rev. Biol. Trop. 63, 501-514. doi: $10.15517 /$ rbt.v63i2.15746

Del Moral-Flores, L. F., Ramírez-Antonio, E., Angulo, A., and Pérez-Ponce de León, G. (2015b). Ginglymostoma unami sp. nov. (Chondrichthyes: Orectolobiformes: Ginglymostomatidae): una especie nueva de tiburón gata del Pacífico oriental tropical. Rev. Mex. Biodivers. 78, 459-482. doi: $10.7550 / \mathrm{rmb} .46192$

Dent, F., and Clarke, S. (2015). State of the Global Market for Shark Products. Rome: FAO.

Dudgeon, C. L., Blower, D. C., Broderick, D., Giles, J. L., Holmes, B. J., Kashiwagi, T., et al. (2012). A review of the application of molecular genetics for fisheries management and conservation of sharks and rays. J. Fish Biol. 80, 1789-1843. doi: 10.1111/j.1095-8649.2012.03265.x

Dulvy, N. K., Fowler, S. L., Musick, J. A., Cavanagh, R. D., Kyne, P. M., Harrison, L. R., et al. (2014). Extinction risk and conservation of the world's sharks and rays. Elife 3:e00590. doi: 10.7554/eLife.00590

Dulvy, N. K., Simpfendorfer, C. A., Davidson, L. N. K., Fordham, S. V., Bräutigam, A., Sant, G., et al. (2017). Challenges and priorities in shark and ray conservation. Curr. Biol. 27, R565-R572. doi: 10.1016/j.cub.2017.04.038

Eschmeyer, W. N., and Fong, J. D. (2017). Species by Family/Subfamily. Available online at: http://researcharchive.calacademy.org/research/ichthyology/catalog/ SpeciesByFamily.asp.

Eschmeyer, W. N., Fricke, R., and van der Laan, R. (2017). Catalog of Fishes: Genera, Species, References. Available online at: http://researcharchive.calacademy.org/ research/ichthyology/catalog/fishcatmain.asp.

Espinoza, M., Clarke, T. M., Villalobos-Rojas, F., and Wehrtmann, I. S. (2012). Ontogenetic dietary shifts and feeding ecology of the rasptail skate (Raja velezi) and the brown smoothhound shark (Mustelus henlei) along the
Pacific coast of Costa Rica, Central America. J. Fish Biol. 81, 1578-1595. doi: 10.1111/j.1095-8649.2012.03410.x

Espinoza, M., Clarke, T. M., Villalobos-Rojas, F., and Wehrtmann, I. S. (2013). Diet composition and diel feeding behaviour of the banded guitarfish Zapteryx xyster along the Pacific coast of Costa Rica, Central America. J. Fish Biol. 82, 286-305. doi: 10.1111/j.1095-8649.2012.03488.x

Espinoza, M., Heupel, M. R., Tobin, A. J., and Simpfendorfer, C. A. (2016) Evidence of partial migration in a large coastal predator: opportunistic foraging and reproduction as key drivers? PLoS ONE 11:e0147608. doi: 10.1371/journal.pone. 0147608

Espinoza, M., Lédée, E. J., Simpfendorfer, C. A., Tobin, A. J., and Heupel, M. R. (2015a). Contrasting movements and connectivity of reef-associated sharks using acoustic telemetry: implications for management. Ecol. Appl. 25, 2101-2118. doi: 10.1890/14-2293.1

Espinoza, M., Munroe, S. E. M., Clarke, T. M., Fisk, A. T., and Wehrtmann, I. S. (2015b). Feeding ecology of common demersal elasmobranch species in the Pacific coast of Costa Rica inferred from stable isotope and stomach content analyses. J. Exp. Mar. Biol. Ecol. 470, 12-25. doi: 10.1016/j.jembe.2015. 04.021

Fargier, L., Hartmann, H. J., and Molina-Ureña, H. (2014). "Marine areas of responsible fishing": a path toward small-scale fisheries co-management in Costa Rica? perspectives from Golfo Dulce," in Fisheries Management of Mexican and Central American Estuaries, eds F. Amezcua and B. Bellgraph (New York, NY: Springer), 155-181.

Fournier, M. L., and Fonseca, A. (2007). Décimo tercer Informe Estado de la Nación en Desarrollo Humano Sostenible: La Zona Marino-Costera. San José.

Frisk, M. G., Miller, T. J., and Dulvy, N. K. (2005). Life histories and vulnerability to exploitation of elasmobranchs: inferences from elasticity, perturbation and phylogenetic analyses. J. Northwest Atl. Fish. Soc. 34, 1-19. doi: 10.2960/J.v35.m514

Frisk, M. G., Miller, T. J., and Fogarty, M. J. (2001). Estimation and analysis of biological parameters in elasmobranch fishes: a comparative life history study. Can. J. Fish. Aquat. Sci. 58, 969-981. doi: 10.1139/f01-051

Froese, R., and Pauly, D. (2017). FishBase. Available online at: http://fishbase.org.

Galván-Tirado, C., Díaz-Jaimes, P., García-de León, F. J., Galván-Magaña, F., and Uribe-Alcocer, M. (2013). Historical demography and genetic differentiation inferred from the mitochondrial DNA of the silky shark (Carcharhinus falciformis) in the Pacific Ocean. Fish. Res. 147, 36-46. doi: 10.1016/j.fishres.2013.03.020

García, V. B., Lucifora, L. O., and Myers, R. A. (2008). The importance of habitat and life history to extinction risk in sharks, skates, rays and chimaeras. Proc. Biol. Sci. 275, 83-89. doi: 10.1098/rspb.2007.1295

Garman, S. (1880). New species of selachians in the museum collection. Bulletin of the Museum of Comp. Zool. 6, 167-172.

Gilman, E., Clarke, S., Brothers, N., Alfaro-Shigueto, J., Mandelman, J., Mangel, J., et al. (2008). Shark interactions in pelagic longline fisheries. Mar. Policy 32, 1-18. doi: 10.1016/j.marpol.2007.05.001

Gill, T. N. (1863). On the classification of the families and genera of the Squali of California. Proc. Acad. Nat. Sci. Philadelphia 14, 483-501.

Griffith, E., and Smith, C. H. (1834). "The class Pisces, arranged by the Baron Cuvier, with supplementary additions by Edward Griffith and others," in The Animal Kingdom, Arranged in Conformity with its Organization, by the Baron Cuvier, Member of the Institute of France, with Supplementary Additions to Each Order (London: Whittaker \& Co.), 1-680.

Griffiths, S., Duffy, L., and Aires-da-Silva, A. (2017). "A preliminary ecological risk assessment of the large-scale tune longline fishery in the Eastern Pacific Ocean using productivity-susceptibility analysis," in Inter-American Tropical Tuna Commission. Scientific Advisory Committee. Eight Meeting (La Jolla, CA).

Hazen, E. L., Jorgensen, S., Rykaczewski, R. R., Bograd, S. J., Foley, D. G., Jonsen, I. D., et al. (2012). Predicted habitat shifts of Pacific top predators in a changing climate. Nat. Clim. Chang. 3, 234-238. doi: 10.1038/nclimate1686

Heithaus, M. R., Alcoverro, T., Arthur, R., Burkholder, D. A., Coates, K. A., Christianen, M. J., et al. (2014). Seagrasses in the age of sea turtle conservation and shark overfishing. Front. Mar. Sci. 1:28. doi: 10.3389/fmars.2014.00028

Herrera-Ulloa, Á., Villalobos-Chacón, L., Palacios-Villegas, J., Viquez-Portuguéz, R., and Oro-Marcos, G. (2011). "Coastal fisheries of Costa Rica," in Coastal Fisheries of Latin America and the Caribbean. FAO Fisheries and Aquaculture 
Technical Paper. No. 544, eds S. Salas, R. Chuenpagdee, A. Charles, and J. C. Seijo (Rome: FAO), 137-153.

Heupel, M. R., Carlson, J. K., and Simpfendorfer, C. A. (2007). Shark nursery areas: concepts, definition, characterization and assumptions. Mar. Ecol. Prog. Ser. 337, 287-297. doi: 10.3354/meps337287

Heupel, M. R., Knip, D. M., Simpfendorfer, C. A., and Dulvy, N. K. (2014). Sizing up the ecological role of sharks as predators. Mar. Ecol. Prog. Ser. 495, 291-298. doi: 10.3354/meps10597

Hossain, M. A., Thompson, B. S., Chowdhury, G. W., Mohsanin, S., Fahad, Z. H., Koldewey, H. J., et al. (2015). Sawfish exploitation and status in Bangladesh. Aquat. Conserv. Mar. Freshw. Ecosyst. 25, 781-799. doi: 10.1002/aqc.2466

Hussey, N. E., Dudley, S. F. J., McCarthy, I. D., Cliff, G., and Fisk, A. T. (2011). Stable isotope profiles of large marine predators: viable indicators of trophic position, diet, and movement in sharks? Can. J. Fish. Aquat. Sci. 2045, 2029-2045. doi: 10.1139/f2011-115

Hussey, N. E., Kessel, S. T., Aarestrup, K., Cooke, S. J., Cowley, P. D., Fisk, A. T., et al. (2015). Aquatic animal telemetry: a panoramic window into the underwater world. Science 348:1255642. doi: 10.1126/science. 1255642

Hussey, N. E., MacNeil, M. A., Olin, J. A., McMeans, B. C., Kinney, M. J., Chapman, D. D., et al. (2012). Stable isotopes and elasmobranchs: tissue types, methods, applications and assumptions. J. Fish Biol. 80, 1449-1484. doi: 10.1111/j.1095-8649.2012.03251.x

IATTC (2016). "Resolution C-16-06 Conservation measures for shark species, with special emphasison the silky shark (Carcharhinus falciformis), for the years 2017, 2018 and 2019," in Inter-American Tropical Tuna Commission. 90th Meeting (La Jolla, CA).

IUCN (2017). The IUCN Red List of Threatened Species. Version 2017-2. Available online at: http://www.iucnredlist.org.

Jirik, K. E., and Lowe, C. G. (2012). An elasmobranch maternity ward: female round stingrays Urobatis halleri use warm, restored estuarine habitat during gestation. J. Fish Biol. 80, 1227-1245. doi: 10.1111/j.1095-8649.2011.03208.x

Jones, M. C., and Cheung, W. W. L. (2015). Multi-model ensemble projections of climate change effects on global marine biodiversity. ICES J. Mar. Sci. 72, 741-752. doi: 10.1093/icesjms/fsul72

Jones, M. C., and Cheung, W. W. L. (2017). Using fuzzy logic to determine the vulnerability of marine species to climate change. Glob. Chang. 24, e719-e731. doi: $10.1111 / \mathrm{gcb} .13869$

Jordan, D. S., and Evermann, B. W. (1896). The fishes of North and Middle America: a descriptive catalogue of the species of fish-like vertebrates found in the waters of North America, north of the Isthmus of Panama. Bull. US Natl. Museum 47, 1-1240.

Jordan, D. S., and Gilbert, C. H. (1882). Descriptions of nineteen new species of fishes from the Bay of Panama. Bull. US Fish Comm. 1, 306-335.

Ketchum, J. T., Hearn, A., Klimley, A. P., Peñaherrera, C., Espinoza, E., Bessudo, S., et al. (2014). Inter-island movements of scalloped hammerhead sharks (Sphyrna lewini) and seasonal connectivity in a marine protected area of the eastern tropical Pacific. Mar. Biol. 161, 939-951. doi: $10.1007 / \mathrm{s} 00227-014-2393-y$

Kitchell, J. F., Essington, T. E., Boggs, C. H., Schindler, D. E., and Walters, C. J. (2002). The role of sharks and longline fisheries in a pelagic ecosystem of the Central Pacific. Ecosystems 5, 202-216. doi: 10.1007/s10021-0010065-5

Kroodsma, D. A., Miller, N. A., and Roan, A. (2017). The Global View of Transshipment: Revised Preliminary Findings. Global Fishing Watch and SkyTruth, July 2017. Available online at: http://globalfishingwatch.org.

Kyne, P. M., Carlson, J. K., Ebert, D. A., Fordham, S. V., Bizzarro, J. J., Graham, R. T., et al. (2012). The Conservation Status of North American, Central American, and Caribbean Chondrichthyans the Conservation Status of North American, Central American, and Caribbean Chondrichthyans. Vancouver, BC: UCN Species Survival Commission Shark Specialist Group.

Latham, J. F. (1794). An essay on the various species of sawfish. Trans. Linnean Soc. Lond. 2, 273-282.

Lay, G. T., and Bennett, E. T. (1839). "Fishes," in The Zoology of Captain Beecheys Voyage: Compiled From the Collections and Notes Made by Captain Bekchey, the Officers and Naturalist of the Expedition, During a Voyage to the Pacific and Behring's Straits Performed in His Majesty's Ship Blossom, ed F. W. Beechey (London: H. G. Bohn), 41-75.
Linnaeus, C. (1758). Systema Naturae, Ed. X. (Systema naturae per regna tria naturae, secundum classes, ordines, genera, species, cum characteribus, differentiis, synonymis, locis. Tomus I. Editio decima, reformata). Holmiae 1, $1-824$.

López-Garro, A., and Zanella, I. (2015). Tiburones y rayas capturados por pesquerías artesanales con línea de fondo en el Golfo Dulce, Costa Rica. Rev. Biol. Trop. 63, 183-198.

López-Garro, A., Arauz-Vargas, R., Ilena, Z., and Le-Foulgo, L. (2009). Análisis de las capturas de tiburones y rayas en las pesquerías artesanales de Tárcoles, Pacífico Central de Costa Rica. Rev. Cienc. Mar. Costeras 1, 145-157.

López-Garro, A., Ilena, Z., Frank, M., Geiner, G.-D., and Maikel, P.-M. (2016). La pesca ilegal en el Parque Nacional Isla del Coco, Costa Rica. Rev. Biol. Trop. 64, 249-262. doi: 10.15517/rbt.v64i1.23454

López, S. M. I., and Bussing, W. A. (1998). Urotrygon cimar, a new eastern Pacific stingray (Pisces: Urolophidae). Revista de Biol. Tropical. 46, 271-277.

Müller, J., and Henle, F. G. J. (1838). Systematische Beschreibung der Plagiostomen. Berlin: Veit und Comp.

Nalesso, E. (2014). Distribución Espacio-Temporal de los Tiburones Martillo, Sphyrna lewini, Alrededor de la Isla del Coco (2005-2013), Pacífico Tropical Oriental. Tesis de Maestría, Centro de Ivestigación Científica Superior de Ensenada, México.

Nance, H., a, Klimley, P., Galván-Magaña, F., Martínez-Ortíz, J., and Marko, P. B. (2011). Demographic processes underlying subtle patterns of population structure in the scalloped hammerhead shark, Sphyrna lewini. PLoS ONE 6:e21459. doi: 10.1371/journal.pone.0021459

Nasar, J., Ketchum, J., Peñaherrera, C., Arauz, R., Bessudo, S., Espinoza, E., et al. (2016). "Part 5. Tracking iconic migratory species among UNESCO World Heritage sites in the Eastern Tropical Pacific," in World Heritage Papers (France: UNESCO), 57-66.

Nielsen Muñoz, V., and Quesada Alpízar, M. A. (2006). Ambientes Marino Costeros de Costa Rica. San José.

Norton, S. L., Wiley, T. R., Carlson, J. K., Frick, A. L., Poulakis, G. R., and Simpfendorfer, C. A. (2012). Designating critical habitat for juvenile endangered smalltooth sawfish in the United States. Mar. Coast. Fish. Dyn. Manag. Ecosyst. Sci. 4, 473-480. doi: 10.1080/19425120.2012. 676606

O'Bryhim, J. R., Parsons, E. C. M., and Lance, S. L. (2017). Forensic species identification of elasmobranch products sold in Costa Rican markets. Fish. Res. 186, 144-150. doi: 10.1016/j.fishres.2016.08.020

Olds, A. D., Connolly, R. M., Pitt, K. A., and Maxwell, P. S. (2012). Habitat connectivity improves reserve performance. Conserv. Lett. 5, 56-63. doi: 10.1111/j.1755-263X.2011.00204.x

Pauly, D. (1990). On Malthusian overfishing. ICLARM Q. 13, 3-4.

Peverell, S. C. (2009). Sawfish (Pristidae) of the Gulf of Carpentaria, Queensland, Australia. Masters thesis, James Cook University.

Pietschmann, V. (1928). Neue Fischarten aus dem Pazifischen Ozean. Anzeiger der Kaiserlichen Akademie der Wissenschaften, Wien, Mathematisch-Naturwissenschaftliche Classe 65, 297-298.

Pistevos, J. C. A., Nagelkerken, I., Rossi, T., Olmos, M., and Connell, S. D. (2015). Ocean acidification and global warming impair shark hunting behaviour and growth. Sci. Rep. 5:16293. doi: 10.1038/srep16293

Queiroz, N., Humphries, N. E., Mucientes, G., Hammerschlag, N., Lima, F. P., Scales, K. L., et al. (2016). Ocean-wide tracking of pelagic sharks reveals extent of overlap with longline fishing hotspots. Proc. Natl. Acad. Sci. U.S.A. 113, 1582-1587. doi: 10.1073/pnas.1510090113

Robards, M., Silber, G., Adams, J., Arroyo, J., Lorenzini, D., Schwehr, K., et al. (2016). Conservation science and policy applications of the marine vessel Automatic Identification System (AIS) - a review. Bull. Mar. Sci. 92, 75-103. doi: 10.5343/bms.2015.1034

Robertson, D. R., and Allen, G. R. (2015). Shorefishes of the Tropical Eastern Pacific: Online Information System. Version 2.0 Smithsonian Tropical Research Institute, Balboa, Panamá. Available online at: http://biogeodb.stri.si.edu/sftep/ en/pages.

Robertson, D. R., and Van Tassell, J. (2015). Shorefishes of the Greater Caribbean: Online Information System. Version 1.0 Smithsonian Tropical Research Institute, Balboa, Panamá. Available online at: http://biogeodb.stri.si.edu/ caribbean/en/pages. 
Rojas, J. R., Campos, J., Segura, A., Moisés, M., Campos, R., and Rodríguez, O. (2000). Shark fisheries in Central America: a review and update. UNICIENCIA $17,49-56$.

Rojas, M. J. R. (2006). Reproducción y alimentación del tiburón enano Mustelus dorsalis (Pisces: Triakidae) en el Golfo de Nicoya, Costa Rica: elementos para un manejo sostenible. Rev. Biol. Trop. 54, 861-871. doi: 10.15517/rbt.v54i3.13683

Rüppell, W. P. E. S. (1837). Neue Wirbelthiere zu der Fauna von Abyssinien Gehörig. Siegmund Schmerber, Frankfurt am Main: Fische des Rothen Meeres. 53-80.

Salas, S., Chuenpagdee, R., Carlos, J., and Charles, A. (2007). Challenges in the assessment and management of small-scale fisheries in Latin America and the Caribbean. Fish. Res. 87, 5-16. doi: 10.1016/j.fishres.2007.06.015

Sandoval-Herrera, N. I., Vargas-Soto, J. S., Espinoza, M., Clarke, T. M., Fisk, A. T., and Wehrtmann, I. S. (2016). Mercury levels in muscle tissue of four common elasmobranch species from the Pacific coast of Costa Rica, Central America. Reg. Stud. Mar. Sci. 3, 254-261. doi: 10.1016/j.rsma.2015.11.011

Selkoe, K. A., Blenckner, T., Caldwell, M. R., Crowder, L. B., Erickson, A. L., Essington, T. E., et al. (2015). Principles for managing marine ecosystems prone to tipping points. Ecosyst. Heal. Sustain. 1, 1-18. doi: 10.1890/EHS14-0024.1

Sergio, F., Caro, T., Brown, D., Clucas, B., Hunter, J., Ketchum, J., et al. (2008). Top predators as conservation tools: ecological rationale, assumptions, and efficacy. Annu. Rev. Ecol. Evol. Syst. 39, 1-19. doi: 10.1146/annurev.ecolsys.39.110707.173545

Shivji, M. S., Chapman, D. D., Pikitch, E. K., and Raymond, P. W. (2005). Genetic profiling reveals illegal international trade in fins of the great white shark, Carcharodon carcharias. Conserv. Genet. 6, 1035-1039. doi: $10.1007 /$ s10592-005-9082-9

Sills, J. (2017). Illegal fishing on the Galápagos high seas. Science 357:1362. doi: 10.1126/science.aap7832

Simpfendorfer, C. A., and Kyne, P. M. (2009). Limited potential to recover from overfishing raises concerns for deep-sea sharks, rays and chimaeras. Environ. Conserv. 36, 97-103. doi: 10.1017/S0376892909990191

Simpfendorfer, C. A., Kyne, P. M., Noble, T. H., Goldsbury, J., Basiita, R. K., Lindsay, R., et al. (2016). Environmental DNA detects Critically Endangered largetooth sawfish in the wild. Endanger. Species Res. 30, 109-116. doi: 10.3354/esr00731

Siu, S., and Aires-Da-Silva, A. (2016). An Inventory of Sources of Data in Central America on Shark Fisheries Operating in the Eastern Pacific Ocean. Metadata report. 7th Meeting of the Scientific Advisory Committee of the IATTC, Document SAC-07-06b(ii), La Jolla, CA.

Spaet, J. L. Y., Nanninga, G. B., and Berumen, M. L. (2016). Ongoing decline of shark populations in the Eastern Red Sea. Biol. Conserv. 201, 20-28. doi: 10.1016/j.biocon.2016.06.018

Sumaila, U. R., Teh, L., Watson, R., Tyedmers, P., and Pauly, D. (2008). Fuel price increase, subsidies, overcapacity, and resource sustainability. ICES J. Mar. Sci. 65, 832-840. doi: 10.1093/icesjms/fsn070

Terborgh, J., and Estes, J. A. (2010). Trophic Cascades: Predators, Prey, and the Changing Dynamics of Nature. Washington, DC: Island Press.

Thomsen, P. F., Møller, P. R., Sigsgaard, E. E., Knudsen, S. W., Jørgensen, O. A., and Willerslev, E. (2016). Environmental DNA from seawater samples correlate with trawl catches of subarctic, deepwater fishes. PLoS ONE 11:e0165252. doi: 10.1371/journal.pone.0165252

Tobin, A. J., Mapleston, A., Harry, A. V., and Espinoza, M. (2014). Big fish in shallow water; use of an intertidal surf-zone habitat by large-bodied teleosts and elasmobranchs in tropical northern Australia. Environ. Biol. Fishes 97, 821-838. doi: 10.1007/s10641-013-0182-y

Trujillo, P., Cisneros-Montemayor, A. M., Harper, S., Zylich, K., and Zeller, D. (2015). Reconstruction of Costa Rica's marine fisheries catches, 1950-2010. Fish. Bethesda 31, 1-16.

Vásquez, V. E., Ebert, D. A., and Long, D. J. (2015). Etmopterus benchleyi n. sp., a new lanternshark (Squaliformes: Etmopteridae) from the central eastern Pacific Ocean. J. Ocean Sci. Fund. 17, 43-55.

Waples, R. S., and Audzijonyte, A. (2016). Fishery-induced evolution provides insights into adaptive responses of marine species to climate change. Front. Ecol. Environ. 14, 217-224. doi: 10.1002/fee.1264

Ward-Paige, C. A., Mora, C., Lotze, H. K., Pattengill-Semmens, C., McClenachan, L., Arias-Castro, E., et al. (2010). Large-scale absence of sharks on reefs in the greater-Caribbean: a footprint of human pressures. PLoS One 5:e11968. doi: 10.1371/journal.pone.0011968

Wehrtmann, I. S., and Cortés, J. (2009). Marine Biodiversity of Costa Rica, Central America. Berlin: Springer and Business Media B.V.

Wehrtmann, I. S., Arana, P. M., Barriga, E., Gracia, A., and Pezzuto, P. R. (2012). Deep-water shrimp fisheries in Latin America: a review. Lat. Am. J. Aquat. Res. 40, 497-535. doi: 10.3856/vol40-issue3-fulltext-2

Weigmann, S. (2016). Annotated checklist of the living sharks, batoids and chimaeras (Chondrichthyes) of the world, with a focus on biogeographical diversity. J. Fish Biol. 88, 837-1037. doi: 10.1111/jfb.12874

White, E. R., Myers, M. C., Flemming, J. M., and Baum, J. K. (2015). Shifting elasmobranch community assemblage at Cocos Island-an isolated marine protected area. Conserv. Biol. 29, 1186-1197. doi: 10.1111/cobi.12478

White, T. D., Carlisle, A. B., Kroodsma, D. A., Block, B. A., Casagrandi, R., De Leo, G. A., et al. (2017). Assessing the effectiveness of a large marine protected area for reef shark conservation. Biol. Conserv. 207, 64-71. doi: 10.1016/j.biocon.2017.01.009

Whoriskey, S., Arauz, R., and Baum, J. K. (2011). Potential impacts of emerging mahi-mahi fisheries on sea turtle and elasmobranch bycatch species. Biol. Conserv. 144, 1841-1849. doi: 10.1016/j.biocon.2011. 03.021

Zanella Cesarotto, I., López Garro, A., and Arauz Vargas, R. (2010). La alimentación de tiburones martillo jovenes (Sphyrna lewini) capturados en el Golfo De Nicoya, Costa Rica. Bol. Investig. Mar. Costeras 39, 447-453.

Zanella, I., and López-Garro, A. (2015). Abundancia, reproducción y tallas del tiburón martillo Sphyrna lewini (Carcharhiniformes: Sphyrnidae) en la pesca artesanal de Golfo Dulce, Pacífico de Costa Rica. Rev. Biol. Trop. 63, $307-317$.

Conflict of Interest Statement: The authors declare that the research was conducted in the absence of any commercial or financial relationships that could be construed as a potential conflict of interest.

Copyright (c) 2018 Espinoza, Díaz, Angulo, Hernández and Clarke. This is an openaccess article distributed under the terms of the Creative Commons Attribution License (CC BY). The use, distribution or reproduction in other forums is permitted, provided the original author(s) and the copyright owner are credited and that the original publication in this journal is cited, in accordance with accepted academic practice. No use, distribution or reproduction is permitted which does not comply with these terms. 